\title{
Managing Teacher Education: The Development of Transformational Leadership Competency Model
}

\author{
Sugunah Supermane
}

Department of Technic and Vocational Education, Institut Pendidikan Guru Kampus Temenggong Ibrahim, 80500 Johor bahru, Johor, Malaysi., E-mail: sugunah559@gmail.com

\begin{abstract}
Transformational leadership is an important competency that should be honed by all the leaders in order to assist teacher educators in upholding the transformation of teacher education. Particularly, transformational leaders play significant roles in communicating and visualising the transformation vision and missions among teacher educators. Thus, this study aimed to develop a substantiated Transformational Leadership Competency Model (TLCM) to capitalize on transformational leadership practice in teachers training colleges. Structural equation modelling was employed to test the models. All the good fit measurement models were validated through confirmatory factor analysis (CFA). Moreover, the study discovered an acceptable convergent validity, discriminant validity, construct validity and internal consistency for the TLCM.

Key words Transformational Leadership, Teacher Educators, Exploratory Factor Analysis, Confirmatory Factor Analysis

Received: 28 Feb $2020 \quad$ C The Authors 2020

Revised: 08 Mar 2020 Published by Human Resource Management Academic Research Society (www.hrmars.com)

Accepted: 12 Mar 2020 This article is published under the Creative Commons Attribution (CC BY 4.0) license. Anyone may Published Online: 17 Mar 2020 reproduce, distribute, translate and create derivative works of this article (for both commercial and non-commercial purposes), subject to full attribution to the original publication and authors. The full terms of this license may be seen at: http://creativecommons.org/licences/by/4.0/legalcode
\end{abstract}

\section{Introduction}

Transformational leadership should be in the limelight in order to produce leaders that are more capable in leading the transformation of teachers training colleges. Specifically, transformational leaders can inspire, motivate and stimulate teacher educators to work efficiently (Supermane et al., 2018). As the innovative teaching and learning culture is the crucial weapon to transform the teacher education, leaders play prominent roles in facililating teacher educators to accomplish the transformation in teachers training colleges. Leaders are found to be very significant in transforming teacher education. Appropriate guidance given through mentoring, encouragement and sharing of best practices by leaders can strengthen the culture of innovative teaching and learning among teacher educators (PPPM 2013-2015 -KPM, 2013).

Furthermore, Zakhiry (2014); Darwish (2014) emphasized the crucial role of leaders in promoting knowledge sharing and knowledge dissemination in order to prevent brain drain because of the retirement process of existing senior educators in teachers training colleges. Consistent with the above statements, Saadat (2015) found that effective leaders play prominent roles in transferring and disseminating individual knowledge in order to enhance the capacity of educational institutions to accomplish the transformation. Aligned with this, leadership is one of the six elements that has been emphasized in the New IPG Ideas or known as Malaysian Teacher Education Transformation Plan. However, there is lack of guidelines and strategies to implement transformational leadership which is they key element in initiating transformation in teacher education (IPGM, 2011). 
As far as policy and teacher education transforming plans are unable to move leaders and teacher educators towards the achievement of the transformation. In relation to that, Supermane (2019) also stressed that transformational leaders should be engaged to influence and encourage the implementation of knowledge management among teacher educators to produce teaching and learning innovation and transformation. Therefore, it turns out that transformational leadership element should be prioritized to develop more competent leaders in order to coordinate the knowledge resources to accomplish the transformation in Malaysian Teachers Training Colleges.

\section{Literature review}

\subsection{Transformational Leadership}

The paradigm shift in leadership has led to the discovery of the concept of transformational leadership by James McGregor Burns in 1978. Furthermore, Bass has made improvements to the theory in 1985 by integrating the elements of psychological needs of members in achieving organizational goals (Politis, 2002) as well as introducing transformation leadership measurement instruments (Bass \& Riggio, 2006).

Transformational leadership is a style of leadership that drives its followers without selfishness through the dimension of idealized influence, inspirational motivation, individual consideration and intellectual stimulation (Bass, 1999). Noruzy et al. (2013) also pointed out that transformational leadership is a management style that inspires the subordinates through passionate speeches, motivations and intellectual stimuli in order to enhance their performance (Soliman, 2014). In this regard, the application of individual individual consideration and intellectual stimulation enable the transformational leaders to generate various methods of thinking, identifying opportunities, problem solving and adopting exploratory thinking processes (García-Morales et al., 2008).

Most of the leaders have achieved remarkable achievements by practicing idealized influence, inspirational motivation, individual consideration and intellectual stimulation. Besides, the practice of transformational leadership contributed directly to the development of subordinates and organizations without the involvement of any legal bondage and barter system (Bass \& Riggio, 2006).

Pounder (2014) found that idealized influence is the central dimension of transformational leadership that drives leaders in sharing the organization's vision and missions among subordinates. The dimension of inspirational motivation exemplifies the leader as a model that needs to be emulated. Through individual consideration, leaders provide persistent personal feedbacks to the subordinates. In addition, consideration on personal needs, capabilities and aspirations is also given attention. On the other hand, intellectual stimulation enables the leaders to guide the subordinated to think creatively and critically to obtain optimum results.

In conclusion, the Transformational Leadership Model by Bass (1985) comprising four major dimensions namely: i) idealized influence ii) inspirational motivation iii) individual consideration and iv) intellectual stimulation in order to enhance the capabilities of an organization. The practice of idealized influence leads the leader to become a role model. The vision and missions of an organization communicated and visualized well among the subordinates through the practice of inspirational motivation. Individual consideration refers to the readiness of leaders to pay attention and give feedbacks to the subordinates. While intellectual stimulation is the ability of the leader to cultivate creative and critical thinking among the subordinates when making decisions.

Hallinger (2003) argued that the focus of transformational leadership in the context of education is to innovate through the enhancement of organizational capabilities in determining goals as well as encouraging the development of improvements in teaching and learning practices. Thus, the transformation leadership led by Bass (1985) is the main variable in this study.

\section{Methodology of research}

The population of this study encompassed 3109 of teacher educators from 27 teachers training colleges across Malaysia. The clustered random sampling method was employed to identify the samples of this study. Gay et al. (2009); claimed that clustered random sampling method is greatly recommended for its efficiency in homogenous population as in education institutions. As for this study, six teachers training 
colleges were chosen randomly based on the different zones (north, south, west, east, Sabah and Sarawak) across Malaysia.

560 questionnaires were distributed to all the teacher educators in the six selected teachers training colleges. Seventy two percent (401) of the samples completed the survey. Unfortunately, the data from 42 samples were excluded from the data analysis as they sent incomplete questionnaires. Thus, the remaining data from 359 samples were used to conduct further analyses. The main instrument of this study was a self-administered questionnaire. Primarily, 26 items were constructed to measure factors such as idealized influence, inspirational motivation, individual consideration and intellectual stimulation. Thereafter, four items were discarded as the derived factor loadings through Exploratory Factor Analysis (EFA) were all below 0.5. Finally, 22 items were retained to develop TLCM through CFA.

\subsection{Confirmatory factor analysis}

Structural equation modelling (SEM) using AMOS version 21 was engaged to test the proposed model. Aligned with the suggestion of Brown (2006), confirmatory factor analysis (CFA) with maximum likelihood estimation was employed to validate the factors and items in the first and second order measurement models. The measurement model was modified in order to demonstrate the best fit. The reliability and validity of the measurement model was confirmed based on the criteria of model fit, convergent validity, discriminant validity and internal consistency. Table 1 below shows all the 22 items included in CFA.

Table 1. Items of TLCM for CFA

\begin{tabular}{|c|c|c|c|c|}
\hline $\begin{array}{l}\text { Item } \\
\text { Code } \\
\text { (CFA) }\end{array}$ & Item & Factors & $\begin{array}{l}\text { Factor } \\
\text { loadings }\end{array}$ & $\begin{array}{c}\text { Cronbach's } \\
\text { Alpha }\end{array}$ \\
\hline PT1 & is able to obtain the trust of educators & \multirow{5}{*}{$\begin{array}{l}\text { idealized } \\
\text { influence }\end{array}$} & 0.776 & \multirow{5}{*}{0.902} \\
\hline PT2 & maintains sense of respect & & 0.768 & \\
\hline PT3 & is dedicated to the educators & & 0.819 & \\
\hline PT4 & acts as the role model & & 0.744 & \\
\hline PT5 & exhibits a high level of self-confidence & & 0.754 & \\
\hline IM1 & takes the initiative to explain IPG's vision & \multirow{5}{*}{$\begin{array}{l}\text { inspirational } \\
\text { motivation }\end{array}$} & 0.859 & \multirow{5}{*}{0.928} \\
\hline IM2 & visualises the IPG's vision using a simple method & & 0.911 & \\
\hline IM3 & explains how to realise IPG's vision & & 0.908 & \\
\hline IM4 & explain the importance of each task given to the educators & & 0.653 & \\
\hline IM5 & motivates educators in order to achieve IPG's vision & & 0.584 & \\
\hline PI1 & $\begin{array}{l}\text { pays attention to the educators' needs on an individual } \\
\text { basis }\end{array}$ & \multirow{7}{*}{$\begin{array}{l}\text { individual } \\
\text { consideration }\end{array}$} & 0.649 & \multirow{7}{*}{0.912} \\
\hline $\mathrm{PI2}$ & assign individual tasks & & 0.566 & \\
\hline $\mathrm{PI3}$ & gives personal feedback on given tasks & & 0.666 & \\
\hline $\mathrm{PI} 4$ & gives special attention to passive educators & & 0.802 & \\
\hline $\mathrm{PI5}$ & allocates time for assisting educators & & 0.837 & \\
\hline $\mathrm{PI} 6$ & allocates time for guiding educators & & 0.807 & \\
\hline $\mathrm{PI7}$ & takes effort to develop the educators' potential & & 0.617 & \\
\hline RI1 & 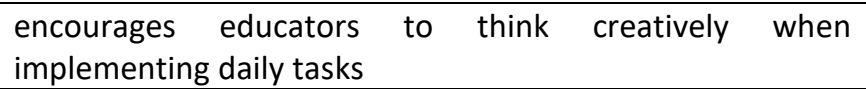 & \multirow{5}{*}{$\begin{array}{l}\text { intellectual } \\
\text { stimulation }\end{array}$} & 0.569 & \multirow{5}{*}{0.904} \\
\hline $\mathrm{RI3}$ & $\begin{array}{l}\text { encourages use of various methods when implementing } \\
\text { the lecturer's daily tasks }\end{array}$ & & 0.834 & \\
\hline RI4 & encourages the lecturer to think out of the box & & 0.852 & \\
\hline RI5 & creates a flexible working environment & & 0.655 & \\
\hline $\mathrm{RI} 6$ & encourages a self reflection among educators & & 0.585 & \\
\hline
\end{tabular}

\subsection{The First Order Measurement Model of TLCM}

CFA was conducted to test the structure of TLCM by employing the maximum likelihood estimation method using AMOS 21 software. A few indices were used to test the good fit of the knowledge 
management model according to the TLCM structure. As shown in Figure 1, the CFA analysis revealed an adequate level of model fit for the proposed model, $\chi^{2} / \mathrm{df}=4.031, \mathrm{CFI}=0.904, \mathrm{TLI}=0.891$ and RMSEA $=0.092$. As for this proposed model, all the residuals were assumed uncorrelated. However, fit indexes for the proposed model were not adequate to meet the good fit thresholds. The well-fitting model is indicated by $\chi^{2} / d f \leq 5, R M S E A \leq 0.080, C F I \geq 0.9$, and TLI $\geq 0.90$ [Hair et al., 2014: Hu \& Bentler, 1998).

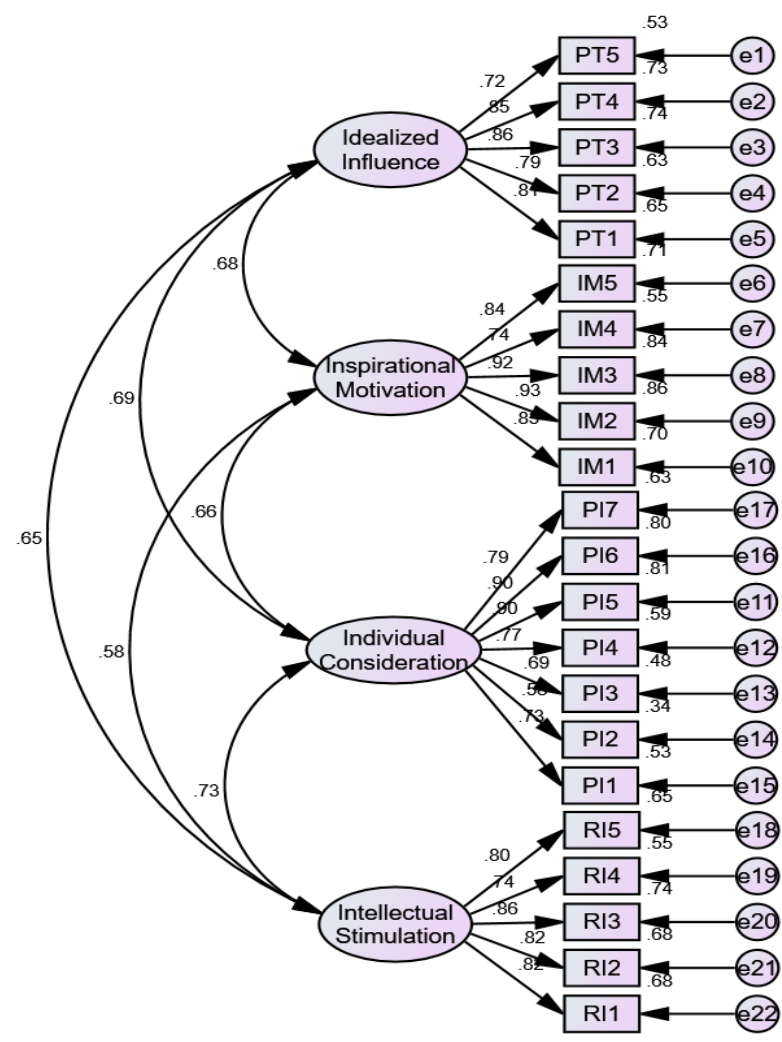

Figure 1. Estimated Factor Loadings for TLCM

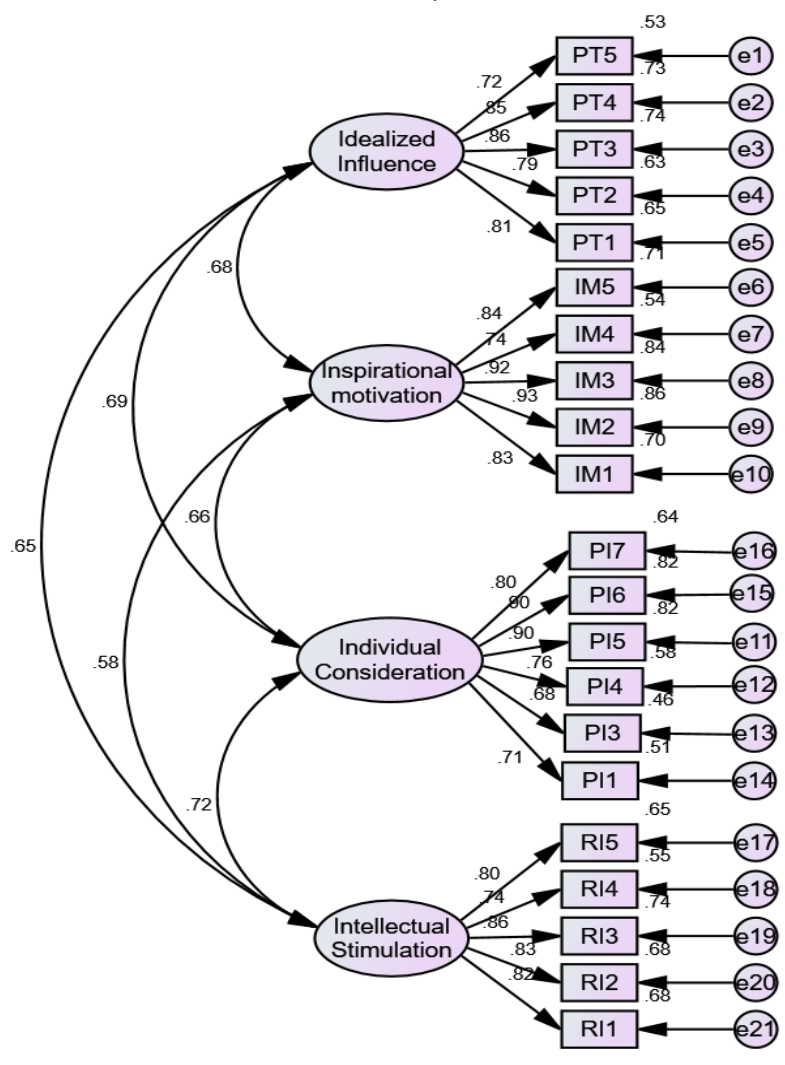

Figure 2. TLCM's First Order Measurement Model 1

Hence, overlapping and low factor loading items needed to be discarded to get a better model fit. In this study, One item (PI2) was discarded for the same reason. Yet, CFA analysis revealed an unacceptable result, $\chi^{2} / d f=3.915, C F I=0.914, T L I=0.901$ and $R M S E A=0.090$. Figure 2 shows the first order measurement model of TLCM without PI2.

In order to get a parsimonious model, modification indices were considered. The findings revealed that correlating the residuals for e4<-->e5 ( $\mathrm{Ml}=37.317)$, e11<-->e15 (Ml=34.978) and e19<-->e20 $(\mathrm{Ml}=26.579)$ would improve the model fit. After the three residuals were correlated, a good fit model was obtained with $\chi^{2} / \mathrm{df}=3.190, \mathrm{CFI}=0.936, \mathrm{TLI}=0.926$ and RMSEA $=0.078$.

Generally, derived results supported the four-factor structure of TLCM. Figure 3 represents a good fitting of first order model of TLCM.

\subsection{The Second Order Measurement Model of EKMCM}

The second order model of TLCM needed to be validated as the construct of transformational leadership consists of four different factors. Figure 4 represents a good fitting second-order measurement model of TLCM. The obtained CMIN/df value of 3.210 met the threshold level of $<5$. Moreover, a high goodness of the model fit also proven with the obtained values of CFI (0.935) and TFI (0.925), which exceeded 0.90. In addition, RMSEA (0.079) showed a complete fit of the model.

The CFA of the four-factor TLCM revealed a good factorial validity, proposing that the fundamentals of the TLCM could be best represented by the four factors (idealized influence, inspirational motivation, individual consideration, intellectual stimulation). 


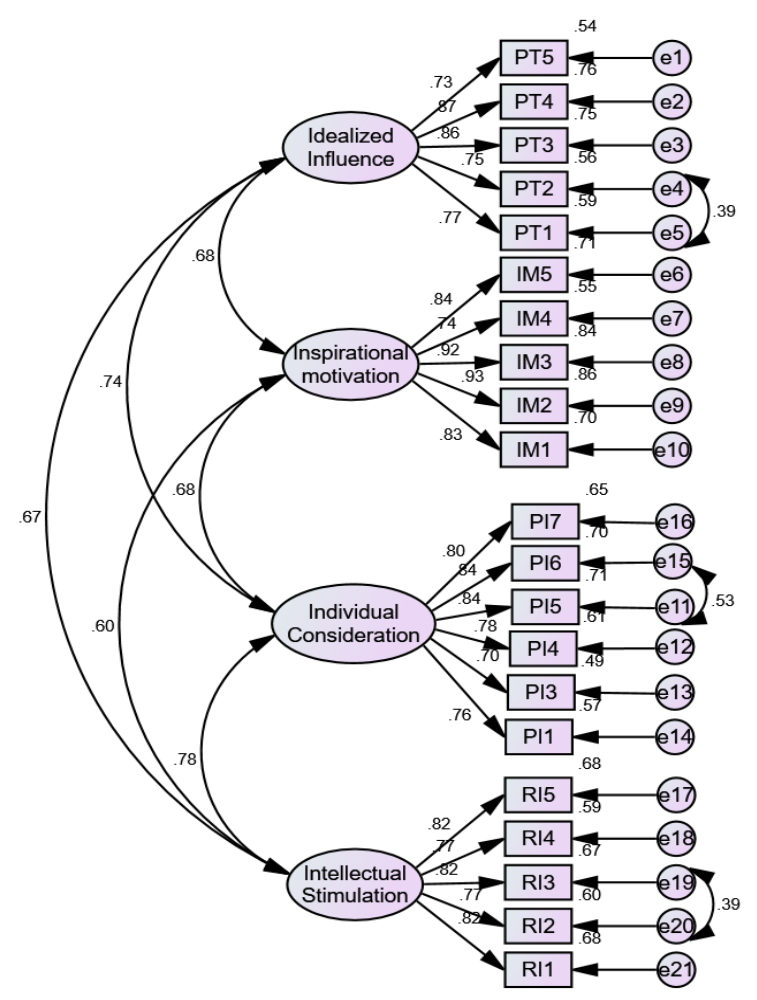

Figure 3.TLCM's First Order Measurement Model 2

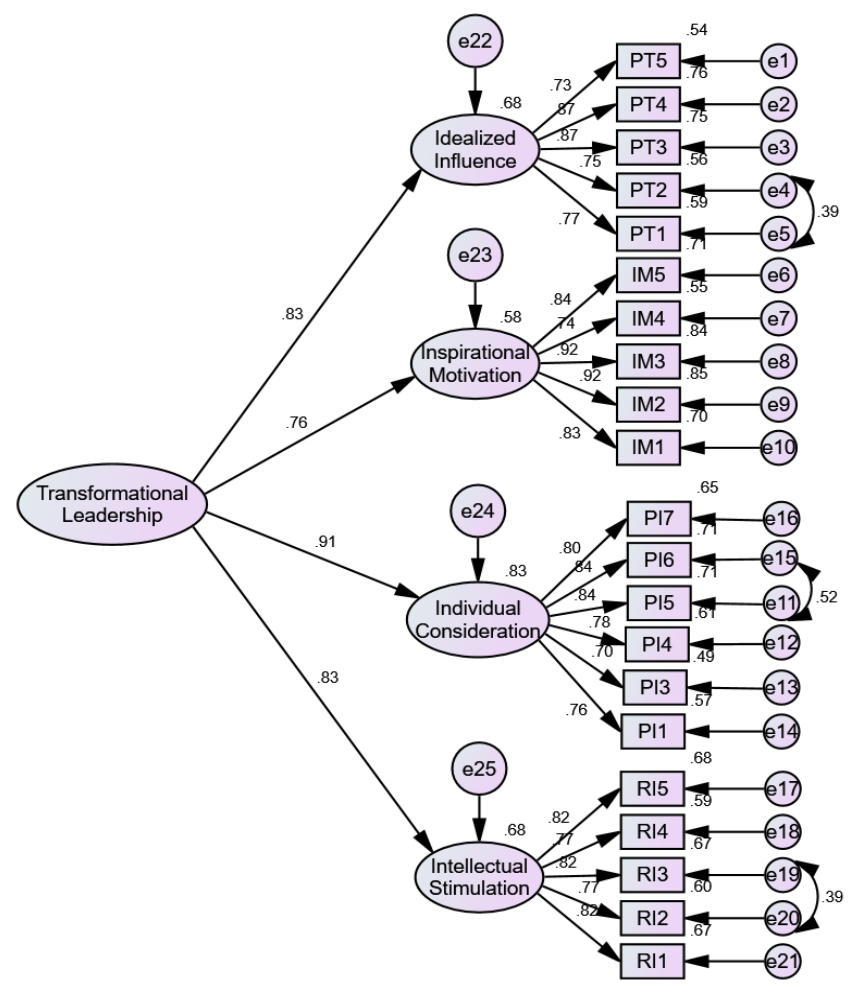

Figure 4. TLCM's Second Order Measurement Model

\subsection{The Validity of TLCM}

The convergent validity for TLCM has been attained as the Average Variance Extracted (AVE) for all four factors of transformational leadership were above 0.60. Precisely, the AVE indexes for idealized influence, inspirational motivation, individual consideration and intellectual stimulation were $0.637,0.731$, 0.621 and 0.634 respectively. In addition, construct validity was achieved earlier as the model obtained a good model fit $\left(\chi^{2} / d f=3.190, C F I=0.936, T L I=0.926\right.$ and RMSEA=0.078). According to Hair et al. (2014), discriminant validity can be attained if the correlations between factors are less than 0.90 . Table 2 represents the results of the correlation analysis done on the four factors. All four factors were not highly correlated as their coefficients were less than 0.90 . Thus, each and every factor was unique and different from each other.

Table 2. Discriminant Validity Index

\begin{tabular}{|l|c|c|c|c|}
\hline \multicolumn{1}{|c|}{ Factors } & $\begin{array}{c}\text { Idealized } \\
\text { Influence }\end{array}$ & $\begin{array}{c}\text { Inspirational } \\
\text { Motivation }\end{array}$ & $\begin{array}{c}\text { Individual } \\
\text { Consideration }\end{array}$ & $\begin{array}{c}\text { Intellectual } \\
\text { Stimulation }\end{array}$ \\
\hline Idealized Influence & $\mathbf{0 . 8 0}$ & & & \\
\hline Inspirational Motivation & 0.68 & $\mathbf{0 . 8 5}$ & & \\
\hline Individual Consideration & 0.74 & 0.68 & $\mathbf{0 . 7 9}$ & \\
\hline Intellectual Stimulation & 0.67 & 0.60 & 0.78 & $\mathbf{0 . 8 0}$ \\
\hline
\end{tabular}

The findings proved that all the four factors were able to measure the construct of transformational leadership effectively.

\subsection{The Reliability of TLCM}

A couple of reliability tests demonstrated a high level of reliability on the factors of idealized influence (PT), inspirational motivation (IM), individual consideration (PI) and intellectual stimulation (RI). Table 3 represents the composite reliability and Cronbach's Alpha coefficient values for all the abovementioned factors. The Cronbach's Alpha coefficient values were in the range of 0.902 to 0.928 (PT=0.902, 
$\mathrm{IM}=0.928, \mathrm{PI}=0.912, \mathrm{RI}=0.904)$. Whereas, the composite reliability $(\mathrm{CR})$ values for all the four factors were in the range of 0.873 to 0.931 .

Specifically, inspirational motivation (IM) was the most reliable factor in transformational leadership as the derived composite reliability value was 0.931 . Next, idealized influence obtained the value of 0.897 , while intellectual stimulation and individual consideration obtained 0.896 and 0.873 respectively.

Table 3. Composite Reliability and Cronbach's Alpha Coefficient Values

\begin{tabular}{|c|c|c|c|c|c|c|}
\hline Factors & Item & $\begin{array}{l}\text { Factor } \\
\text { Loadings } \\
\text { (FL) }\end{array}$ & $(\mathrm{FL})^{2}$ & $\begin{array}{l}\text { Variance } \\
\text { Error } \\
(\mathrm{VR})= \\
1-(\mathrm{FL})^{2}\end{array}$ & $\begin{array}{c}\text { Composite } \\
\text { Reliability (CR) }\end{array}$ & $\begin{array}{c}\text { Cronbach } \\
\text { Alpha }\end{array}$ \\
\hline \multirow[t]{6}{*}{ Idealized Influence (PT) } & PT1 & 0.77 & 0.5929 & 0.4071 & \multirow{6}{*}{$\begin{array}{c}\sum(\mathrm{FL})^{2} / \Sigma(\mathrm{FL})^{2}+\sum(\mathrm{RV}) \\
=(3.98)^{2} / \\
(3.98)^{2}+1.8152 \\
=\mathbf{0 . 8 9 7}\end{array}$} & \multirow{6}{*}{0.902} \\
\hline & PT2 & 0.75 & 0.5625 & 0.4075 & & \\
\hline & PT3 & 0.86 & 0.7396 & 0.2604 & & \\
\hline & PT4 & 0.87 & 0.7569 & 0.2431 & & \\
\hline & PT5 & 0.73 & 0.5329 & 0.4671 & & \\
\hline & Total & 3.98 & 3.1848 & 1.8152 & & \\
\hline \multirow[t]{6}{*}{ Inspirational Motivation (IM) } & $\mathrm{IM} 1$ & 0.83 & 0.6889 & 0.3111 & \multirow{6}{*}{$\begin{array}{c}\sum(\mathrm{FL})^{2} / \sum(\mathrm{FL})^{2}+\sum(\mathrm{RV}) \\
=(4.26)^{2} / \\
(4.26)^{2}+1.3466 \\
=\mathbf{0 . 9 3 1}\end{array}$} & \multirow{6}{*}{0.928} \\
\hline & $\mathrm{IM} 2$ & 0.93 & 0.8649 & 0.1351 & & \\
\hline & IM3 & 0.92 & 0.8464 & 0.1536 & & \\
\hline & IM4 & 0.74 & 0.5476 & 0.4524 & & \\
\hline & IM5 & 0.84 & 0.7056 & 0.2944 & & \\
\hline & Total & 4.26 & 3.6534 & 1.3466 & & \\
\hline \multirow[t]{7}{*}{ Individual Consideration (PI) } & PI1 & 0.76 & 0.5776 & 0.4224 & \multirow{7}{*}{$\begin{array}{c}\sum(\mathrm{FL})^{2} / \Sigma(\mathrm{FL})^{2}+\sum(\mathrm{RV}) \\
=(3.96)^{2} / \\
(3.96)^{2}+2.2728 \\
=\mathbf{0 . 8 7 3}\end{array}$} & \multirow{7}{*}{0.912} \\
\hline & $\mathrm{PI} 3$ & 0.70 & 0.4900 & 0.5100 & & \\
\hline & $\mathrm{PI} 4$ & 0.78 & 0.6048 & 0.3916 & & \\
\hline & PI5 & 0.84 & 0.7056 & 0.2944 & & \\
\hline & $\mathrm{PI} 6$ & 0.84 & 0.7056 & 0.2944 & & \\
\hline & P17 & 0.80 & 0.6400 & 0.3600 & & \\
\hline & Total & 3.96 & 3.7272 & 2.2728 & & \\
\hline \multirow[t]{6}{*}{ Intellectual Stimulation (RI) } & RI1 & 0.80 & 0.6400 & 0.3600 & \multirow{6}{*}{$\begin{array}{c}\sum(\mathrm{FL})^{2} / \Sigma(\mathrm{FL})^{2}+\sum(\mathrm{RV}) \\
=(3.98)^{2} / \\
(3.98)^{2}+1.8294 \\
=\mathbf{0 . 8 9 6}\end{array}$} & \multirow{6}{*}{0.904} \\
\hline & $\mathrm{R} / 2$ & 0.77 & 0.5929 & 0.4071 & & \\
\hline & $\mathrm{RI3}$ & 0.82 & 0.6724 & 0.3276 & & \\
\hline & $\mathrm{R} 14$ & 0.77 & 0.5929 & 0.4071 & & \\
\hline & RI5 & 0.82 & 0.6724 & 0.3276 & & \\
\hline & Total & 3.98 & 3.1706 & 1.8294 & & \\
\hline
\end{tabular}

As for this study, high consistency for all the items when measuring the factors has been proven by the findings from reliability tests. Comprehensively, these findings provide satisfactory evidence of TLCM's reliability based on the thresholds suggested by Hu and Bentler (1998).

\section{Conclusions}

Despite the implementation of ideas, plans and strategies to transform teacher education, leaders in teachers training colleges need to be exposed to transformational leadership competency to lead the transformation. Thus, intensive efforts need to be taken by teachers training colleges in equipping leaders with this competency before they can uphold the vision and missions of teacher education transformation among teacher educators. It will be impossible to lead the transformation if leaders themselves are not competent enough in transformational leadership.

Hence, optimistic leaders can adapt TLCM as primary guidelines to implement transformational leadership as an initial effort to lead teacher educators towards teacher education transformation. By developing an empirically tested model and a validated instrument to identify leaders' transformational leadership competency, the researchers expect that this study contributes to a better understanding of transformational leadership in teachers training colleges. 


\section{References}

1. Bass, B. M. (1985). Leadership and Performance beyond Expectations. New York: Free Press; Collier Macmillan.

2. Bass, B. M. (1999). Two decades of research and development in transformational leadership. European Journal of Work and Organizational Psychology, 8(1), 9-32.

3. Bass, B. M., \& Riggio, R. E. (2006). Transformational leadership (2 ${ }^{\text {nd }}$ ed.). New Jersey: Lawrence Erlbaum Associates Inc.

4. Brown,T. A. (2006). Confirmatory factor analysis for applied research. New York, NY: The Guilford Press.

5. Darwish, S. (2014). Education and Human Capital Development in Bahrain:" Future International Collaboration with Malaysia. International Journal of Academic Research in Management (IJARM), 3(4), 321-334.

6. García-Morales, V. J., Lloréns-Montes, F. J., \& Verdú-Jover, A. J. (2008). The effects of transformational leadership on organizational performance through knowledge and innovation. British Journal of Management, 19(4), 299-319.

7. Hair, J. F., Black, W. C., Babin, B. J., Anderson, R. E., \& Tatham, R. L. (2014). Multivariate data analysis ( $7^{\text {th }}$ ed.). Edinburgh: Pearson.

8. Hallinger, P. (2003). Leading educational change: Reflections on the practice of instructional and transformational leadership. Cambridge Journal of Education, 33(3), 329-352.

9. Hu, L. T., \& Bentler, P. M. (1998). Fit indices in covariance structure modeling: Sensitivity to underparameterized model misspecification. Psychological methods, 3(4), 424.

10.Institut Pendidikan Guru Malaysia-IPGM. (2011). The New IPG-Learner Centered University. Cyberjaya, Malaysia: IPGM.

11.Kementerian Pendidikan Malaysia-KPM. (2013). Pelan pembangunan pendidikan Malaysia 20132025. Kuala Lumpur, Malaysia: Percetakan Nasional Berhad.

12.Mohd Zakhiry. (2014). Kompetensi teknologi maklumat dan telekomunikasi serta pengurusan pengetahuan pensyarah Institut Pendidikan Guru. (Tesis Sarjana), Universiti Teknologi Malaysia, Malaysia.

13.Noruzy, A., Dalfard, V. M., Azhdari, B., Nazari-Shirkouhi, S., \& Rezazadeh, A. (2013). Relations between transformational leadership, organizational learning, knowledge management, organizational innovation, and organizational performance: an empirical investigation of manufacturing firms. The International Journal of Advanced Manufacturing Technology, 64(5-8), 1073-1085.

14.Politis, J. D. (2002). Transformational and transactional leadership enabling (disabling) knowledge acquisition of self-managed teams: The consequences for performance. Leadership \& Organization Development Journal, 23(4), 186-197.

15.Pounder, S. J. (2014). Quality teaching through transformational classroom leadership. Quality Assurance in Education, 22(3), 273-285.

16.Saadat, M., \& Corresponding, K. (2015). Role of transformational leadership in effective knowledge management. Information and Knowledge Management, 5(2), 125-130.

17.Soliman, Fawzy. (2014). Attributes of the learning-innovation transformational leader. In Learning models for innovation in organizations: Examining roles of knowledge transfer and human resources management (251-267). USA: IGI Global.

18.Supermane, S. (2019). Transformational leadership and innovation in teaching and learning activities: the mediation effect of knowledge management. Information Discovery and Delivery, 47(4), 242250.

19.Supermane, S., Tahir, L. M., \& Aris, M. (2018). Transformational Leadership in Teacher Education. International Journal of Academic Research in Business and Social Sciences, 8(3), 267-275. 